This is a self-archived version of an original article. This version may differ from the original in pagination and typographic details.

Author(s): Näyhä, Annukka

Title: Backcasting for desirable futures in Finnish forest-based firms

Year: 2021

Version: Accepted version (Final draft)

Copyright: @ 2020 Emerald Publishing Limited

Rights: $C C$ BY-NC 4.0

Rights url: https://creativecommons.org/licenses/by-nc/4.0/

Please cite the original version:

Näyhä, A. (2021). Backcasting for desirable futures in Finnish forest-based firms. Foresight, 23(1), 50-72. https://doi.org/10.1108/FS-01-2020-0005 


\title{
Backcasting for desirable futures in Finnish forest-based firms
}

Research paper

\begin{abstract}
Purpose

In Finland, new forest-based sector (FBS) businesses are seen as important for the transition to the circular bioeconomy. The goal of this study is to explore the transition of Finnish FBS companies to new business models. The aim is to understand how FBS companies define their ideal future states and related business models for the year 2030.
\end{abstract}

\section{Approach}

The study uses thematic interviews with managers from various FBS firms and companies from interfacing sectors. In the interviews, the key idea of backcasting was pursued when respondents discussed the desirable future states of their business.

\section{Findings}

The effort to achieve growth of the business and the appearance of new products characterize the company-specific desirable future states. In these desirable futures, expanded businesses will be based on strong knowledge. Resource efficiency and collaboration create a strong basis for the desirable future state of the whole FBS to create a sustainable and innovative "Wood Valley".

\section{Research limitations}

The key limitations are that the backcasting process has been conducted only through interviews and a participative approach with stakeholder dialogue is lacking in the process. This means that the desirable futures are created by the FBS companies only.

\section{Implications and value}

As a practical contribution, the study shows the future-oriented thinking and goals of FBS firms. As a theoretical contribution, it extends research on sustainable business models and discussions on the novel field of corporate foresight.

Keywords: circular bioeconomy, corporate foresight, backcasting, sustainable business models, forest-based sector (FBS), Finland 


\section{Introduction}

Sustainability is one of the most sought-after goals in modern society. The concept of sustainability has been part of public and private sector policies for many decades. There is a wide consensus that sustainable development requires systemic change in our production and consumption patterns. Both practitioners and academia increasingly highlight the importance of business models for attaining systemic change (e.g. Loorbach and Wijsman, 2013; Schaltegger et al., 2016; Baumgartner and Rauter, 2017; Bidmon and Knab, 2018).

However, it appears that aims to develop specific methods for creating sustainable strategies have often been inadequate in companies. Schaltegger et al. (2016) argue that more research on business models for sustainability is needed to facilitate sustainability management, which in turn can contribute to sustainable societal development. These challenges are described in many other recent studies. For example, Baumgartner and Rauter (2017) highlight that a lack of strategic orientation in corporate sustainability management is one of the key reasons for insufficient development in the field. Sarasini and Linder (2019) emphasize the need to better understand the role of new business models and related business model innovations in broader systemic transitions as well as how sustainability transitions based on new business models may be governed.

Foresight ${ }^{1}$ can be defined as "the assessment of what might happen or be needed in the future" (Global Foresight Group, 2019). Moreover, foresight and sustainable development have been recognized as being interlinked for many decades. Yet even futurists have underestimated the relationship between sustainable development and foresight (Destatette, 2010).

Creating business strategies in companies is intrinsically connected with strategic foresight, as the strategies are often linked with the analysis of the emerging change drivers that can affect the competitiveness of the company (Bishop and Hines, 2007; Vecchiato and Roveda, 2010). Different approaches have been developed for company managers to be better able to detect timely drivers of change. However, the traditional strategic management analysis frameworks are often not sufficient, because in addition to detecting the emerging drivers, more emphasis should be put on understanding their consequences. Overall, the integration of foresight approaches in company management is, in many aspects, defective (Vecchiato and Roveda, 2010; Hines and Gold, 2015). Even though applying foresight in companies would enable firms to more efficiently anticipate and influence the future, thus making it beneficial in many ways (Hines and Gold, 2015), integrating foresight "has proved to be challenging and rare" (Hines and Gold, 2015, p. 99).

\footnotetext{
${ }^{1}$ There are different terms in different disciplines, fields and discourses which are used to describe studies or assessments of alternative futures. In this study, the term foresight is applied. The reason for this is that the concept of foresight seems to be well known from a variety of instances. Particularly, company representatives demonstrated their familiarity with the term. Overall, it appears that foresight (compared to the term future studies) is often more associated with practical work (e.g. government work, businesses, technological forecasting; see e.g. Sardar 2010, Martin, 2010). In addition, corporate foresight (introduced and defined in the following section 2.1) will be applied throughout this manuscript to indicate the more elaborate focus of the study on strategic foresight in organizations (see Rohrbeck et al., 2015).
} 
In Finland, new forest-based sector (FBS) ${ }^{2}$ businesses are seen as important for the transition to a more sustainable circular bioeconomy (e.g. Ministry of Economy and Employment of Finland, 2014; Hetemäki et al., 2017; D'amato et al., 2019). Many FBS firms are developing new business models based on novel wood-based products and materials, such as bioenergy, raw material for textiles, nanofibers, biocomposites, bioplastics, biopolymers, food additives or pharmaceutics. Apart from larger-scale biorefineries, the potential for smaller-scale, decentralized, higher value-added production alongside various services is increasingly highlighted (e.g., Ollikainen, 2014; Näyhä et al., 2014; Näyhä et al., 2015; Hetemäki, 2017; Hurmekoski et al., 2018).

However, it is often argued - particularly in the Finnish societal discussion - that clearer visions for the future of the sector would be needed to facilitate transition. In addition, there is considerable societal discussion and demands for more research and exchange of ideas on the sustainability of bio- and circular economy business models, goals and visions and, overall, what sustainable new FBS business models are or would be in practice (e.g. Hiilamo, 2019; Kauppinen, 2019; Ollikainen and Seppälä, 2019; Rinta-Jouppi, 2019; Räinä, 2019)

The goal of this study is to explore the transition of Finnish forest-based sector companies to new business models. The starting point is the current position of the companies in the markets, as defined by the companies themselves. The main aim is to obtain understanding of how forest-based sector companies define their ideal future states in 2030 as well as the related roles and business models. More specifically, company representatives were asked first to define the desirable future states for their own businesses and, second, for the whole Finnish forest-based sector. The study also describes company views on the required steps and pathways for transition. The presented procedure followed the basic ideology of backcasting, which is a foresight approach often applied in the context of sustainability related challenges (backcasting will be introduced in more detail in section 2.2). As a practical contribution, this study aims to shed light on future-oriented thinking and the mindset of FBS firms, particularly their managers' views. This knowledge could benefit various societal groups, including FBS actors themselves, academics in forest, management and foresight sciences, and public sector decision-makers. As a theoretical contribution, the study contributes to sustainable business models research as well as to discussion in the novel field of corporate foresight.

\section{Theoretical and conceptual background}

\subsection{Corporate foresight}

The ability to anticipate the future begins early in human beings' lives (Bell, 2003). Everybody, including different organizations, use foresight in their everyday lives and practices. However, such use is often not systematic; meaning that the use is not based on approaches or concepts

\footnotetext{
${ }^{2}$ In this research, the term forest-based sector (FBS) companies is understood to include, in addition to companies in the sector, companies which interface with the FBS or utilize raw material and side-streams from the FBS.
} 
created by professionals working on the field of foresight or future studies (Hines and Gold, 2015). The overall goal of future studies or foresight is to give an increased understanding about different future opportunities, and thus, to enable preparing for the future (Bell, 2003; Miles, 2010; Rohrbeck et al. 2015). Further, concept of foresight is based on three suppositions: first, multiple futures are possible, meaning that uncertainty and unpredictability are connected to futures developments; second, change drivers can be recognized and studied, and third, it is possible to have an impact on the future (Berger et al. 2008 in Rohrbeck et al. 2015)

Vecchiato (2015) argues that the one of the most critical challenges in companies is creating a strategy for the future. According to Rohrbeck et al. (2015), corporate foresight emerged in the 1950s in research driven particularly by Gaston Berger (the prospective school) and Herman Kahn (the foresight school). Despite its importance in a rapidly changing and complex environment, the issue has often been overlooked, particularly in successful companies (Vecchiato, 2015). The main aim of corporate foresight is to help company managers understand and affect the future and its uncertainties (Rohrbeck et al. 2015). Rohrbeck et al. (2015, p. 2) defines corporate foresight as:

Corporate foresight permits an organization to lay the foundation for future competitive advantage. Corporate foresight is identifying, observing and interpreting factors that induce change, determining possible organizationspecific implications, and triggering appropriate organizational responses. Corporate foresight involves multiple stakeholders and creates value through providing access to critical resources ahead of competition, preparing the organization for change, and permitting the organization to steer proactively towards a desired future.

Moreover, Rohrbeck et al. (2015) note that focusing discussions on the collective concept of corporate foresight would be needed because it integrates theoretical reasoning from management theories and empirical findings from strategic foresight research along with accelerating knowledge creation on an organization's survival in uncertain environments.

Cultural resistance to applying foresight approaches have been previously observed in companies (Rohrbeck et al., 2008; Hines and Gold, 2015). Slaughter (2009) points out that the use of foresight in firms has been rarer than it has in governments or research institutes. Hines and Gold (2015) stress that company foresight work is often periodic and managed by external consultants. Knowledge available on organizational frameworks applied by the companies to coordinate foresight activities is also scarce (Vecchiato, 2012). There has also been criticism about the effectiveness of corporate foresight, emphasizing that it is impossible to make reliable visions of the future (i.e. the longer the time span of the foresight study, the more the accuracy of the forecast decreases). Academics and practitioners in the strategic foresight fields tend to respond to critics by emphasizing that the role of the foresight is not actually to anticipate the future as it will be exactly. Instead, the aim is to increase the preparedness of the company for future challenges (Vecchiato, 2015). 
It appears that the challenge of surviving within a continuously changing environment that contains many threats has increased the interest of practitioners as well as of academia in corporate foresight by (Vecchiato, 2012; Rohrbeck et al., 2015; Vecchiato, 2015). Recent studies indicate the positive impact of corporate foresight on firm performance (Rohrbeck and Kum, 2018; Rohrbeck et al., 2018). Rohrbeck et al. (2015) emphasizes that the current focus should be on the integration of foresight with existing processes and managerial systems in the companies. This would facilitate the strategic responsiveness and innovation capacity of the firms. A new challenge for the companies is also to involve stakeholders that are somehow affected by the company actions in the foresight process (known as participatory foresight; Bas and Guillo, 2015; Kaivo-oja, 2017). In open foresight, firms share their understanding and interpretations of future developments with other companies, thus integrating external knowledge into their foresight processes (the open foresight concept has confluences with open innovation, see e.g. Chesbrough, 2003). This approach can overcome some of the key limitations of traditional corporate foresight, such as relying on internal capabilities only (Daheim and Uerz, 2008; Wiener, 2017; Wiener and Boer, 2019).

In future and foresight studies, creating strategies for the future has long been done through scenario work. Most scenarios aim to extrapolate from the current situation to the future, that is, they are forward looking. Scenarios can be classified into three categories based on which question they aim to answer: what will happen (trend extrapolations, business as usual scenarios); what could happen (forecasting, foresighting, strategic scenarios) and what should happen (normative scenarios). Normative scenarios are often known as "desirable futures" or "future visions" (Vergragt and Quist, 2011).

\subsection{Backcasting}

The backcasting approach can be defined as "generating a desirable future, and then looking backwards from that future to the present in order to strategize and to plan how it could be achieved" (Vergragt and Quist, 2006; Quist, 2007; Vergragt and Quist, 2011, p. 747). In other words, backcasting can be viewed as an alternative or complement to traditional forecasting: it is a form of scenario analysis where a desirable future state(s) is first imagined, and then the subsequent steps preceding it are formulated (Vergragt and Quist, 2011; Heinonen and Lauttamäki, 2012). Wangel (2011, p. 872) encapsulates aptly the purpose of backcasting studies: "one main characteristic of backcasting studies is the development of one or more goal-fulfilling images of the future, answering the question of how a certain target can be met when contemporary structures block the changes sought".

Backcasting was initially developed as an alternative to traditional energy forecasting in the 1970s (e.g. Lovins, 1977; Robinson, 1982). Later, backcasting has been increasingly applied in the context of various sustainability challenges (Robinson et al., 2011; Vergragt and Quist, 2011). Since backcasting is about future states we would like to attain, it is explicitly normative. The concept of sustainability is also strongly normative, thus it is not surprising that backcasting has become more widely applied in sustainability-related challenges (Vergragt and Quist, 2011). 
A backcasting approach is flexible and contextual in nature, and a number of different approaches and methodologies can be applied in backcasting (e.g. Quist and Vergragt, 2006; Höjer et al., 2011; Wangel, 2011, Bibri 2018). There are differences, for example in the topics and scales of the systems, number and ways of visions produced, focus of the studies, stakeholder involvement and applied methods (Vergragt and Quist, 2011; Quist et al. 2011). In addition, the selected time periods vary in the studies, being typically between 25 and 50 years (Robinson, 2003; Vergragt and Quist, 2011). There is also variation in applied terminology. For example, normative scenarios can also be called desirable futures, visions, or future visions (Vergragt and Quist, 2011). Wangel (2011) states that, depending on the goal, different backcasting approaches have their own rationale. Overall, due to this variation, backcasting should be viewed more as a general approach rather than as a specific method (Dreborg, 1996). Vergragt and Quist (2011) also point out that the diversity in application should be seen as a strength of the approach, yet terms and concepts need to be described in detail in every study.

According to Wangel (2011) in backcasting studies key differences in interpretations relate to the question of if the future image has to be developed as goal-fulfilling or not, and if it is obligatory or optional to describe the transition pathways. The degree of participation of different stakeholders (versus experts) in the backcasting process is also an important issue to be decided. Wangel (2011) recognizes two primary approaches for backcasting: a resultorientated approach, and backcasting as a participation-orientated creative workshop technique (where participation per se is the overarching goal). She also presents a further categorization of result-oriented backcasting studies into three categories (which are not exclusive to each other): target-oriented backcasting (what can change); pathway-oriented backcasting (how change could happen); and action-oriented back casting (who could realize the change).

In the context of sustainability-related challenges, a participatory backcasting approach is often chosen (Quist et al., 2011; Kishita et al., 2017). In participatory backcasting, different stakeholders can express their opinions on what futures are desirable. Participating stakeholder groups can include, for example, firms, research institutes, government, NGOs and the public (Quist and Vergragt, 2006). Throughout the backcasting process, participants can express their own views on desirable futures, discuss the ideas with the other participants, and at the same time learn the consequences associated with those preferences. In other words, a potential positive result of the participatory backcasting processes is increased social learning (Robinson, 2003; Robinson et al., 2011).

Bibri (2018) presents a synthesized methodological framework for backcasting, which based on different approaches (Bibri, 2018 citing Holmberg and Robèrt, 2000; Quist and Vergragt, 2006; Carlsson Kanyama et al. 2008; Quist, 2009). It includes five phases: domain and demographics (current state, target areas, relevant stakeholders), future visions (definition, description), steps (developing actions for reaching the future vision, evaluating the feasibility of these actions, choosing relevant perspectives for consideration), analysis (assessing the created future image in terms of establishing an action plan) and implementation (formulating an action plan, addressing main stakeholders for the implementation). 
As discussed above, backcasting can be applied in various contexts and levels (organizations, regions, industries, sociotechnical systems, national/global scale; see e.g. Dreborg, 1996; Quist and Vergragt, 2006; Vergragt and Quist, 2011). Thorén and Vendel (2018) emphasize that backcasting can help organizations challenge current mindsets, thus widen the views on different alternatives when analyzing different (long-term) future options. Based on their review, backcasting has a large potential as a tool for strategy development particularly under VUCA (volatile, uncertain, complex, ambiguous) conditions. 7). As Thorén and Vendel summarize it (2018, p. 309), "Backcasting allows for sharing of visions and discussion of purpose, which can be a starting point for a web of reason enabling managers to think effectively about the future early on, prepare for it before it comes, and deal with it when it is upon us."

Despite the benefits, backcasting has rarely been applied in business contexts, and the topic has not received enough attention in business management research. To date, backcasting has been mentioned mostly in the innovation management literature. Business executives are often more willing to apply more sophisticated future approaches such as Delphi or trend extrapolation, although backcasting might often be the more suitable method, for example when creating long-term strategies (Thorén and Vendel, 2018). It seems that an important reason for the infrequent use of backcasting in business management is the lack of knowledge of real cases. Related to this lack, Thorén and Vendel (2018) highlight that more systematic empirical mapping and studies on the advantages and shortcomings as well as on managers' experiences with the combined application of foresight and strategy tools in a VUCA environment would be needed. In corporate sustainability studies, foresight and backcasting have been indicated as approaches that can facilitate managers to make such decisions which do not restrict the choices of future decision-makers (Thorén and Vendel, 2018). Furthermore, a framework for strategic sustainable development (FSSD) has been introduced for backcasting from visions framed by a definition of sustainability. There are already many case examples indicating that FSSD facilitates the attainment of a thorough understanding of sustainability challenges and can help in strategic change processes of organizations towards sustainability. Yet widespread application of FSSD remains rare (Broman and Robert, 2017). Overall, it would be important to have more studies with concrete examples of how backasting can be applied in the context of different businesses and related challenges to facilitate its wider scale use.

\subsection{Corporate sustainability}

Nowadays, there is a broad consensus on the relevancy of corporate sustainability for firms. Despite this mutual understanding, actual implementation, meaning concrete actions to transform sustainability strategy into practice, has been given much less attention (Engert and Baumgartner, 2015). According to Dyllick and Hockerts (2002, p. 131) corporate sustainability can be defined as "meeting the needs of a firm's direct and indirect stakeholders (such as shareholders, employees, clients, pressure groups, communities etc.), without compromising its ability to meet the needs of future stakeholders as well." Upward and Jones (2016, p.103) define a strongly sustainable firm as "an organization that creates positive environmental, social, and economic value throughout its value network, sustaining the possibility that human and other life can flourish on this planet forever." 


\subsubsection{Sustainable business models and innovation for sustainability}

Sustainable business models are built around a triple bottom line approach, considering various stakeholders views on economic, social and environmental perspectives (Bocken et al., 2014). Rauter et al. (2017) argue that even though business models incorporating sustainability perspectives do not differ notably from traditional business models, specific adaptations and extensions are needed. Schaltegger et al. (2016) highlight extending the conventional perspective of the business model, which is designed around a value proposition for the customer - to include creating value to wider groups of stakeholders.

Bocken et al. (2014) have presented sustainable business model archetypes for describing mechanisms that can facilitate formulating the business model for sustainability. The key idea behind these eight archetypes is to create a common language to facilitate the development of sustainable business models in practice and in research. The archetypes are, building on the categorization by Boons and Lüdeke-Freund (2013), classified under technological, social and organizational-oriented innovations. The technological grouping includes three archetypes: (a) maximize material end energy efficiency; (b) create value from waste; and (c) substitute with renewables and natural processes. The social grouping contains the archetypes (a) deliver functionality rather than ownership; (b) adopt a stewardship role, and (c) encourage sufficiency. The organizational grouping consists of (a) repurpose for society/environment and (b) develop scale-up solutions.

Boons and Lüdeke-Freund (2013) argue that it would be important to develop a research agenda that combines the key aspect of creating sustainable value through business models for sustainable innovation. Accordingly, Bocken et al. (2014) emphasize that sustainable business models are essential for driving and implementing organizational innovation for sustainability. Bocken et al. $(2019$, p. 6$)$ also propose an integrative definition of innovation for sustainability (IfS): "the intentional introduction of (radically) new or (incrementally) improved products and services or entire systems, which, based on traceable comparative analysis, lead to environmental and (or) social benefits that surpass those of the prior products, services, or systems." However, the authors emphasize that although the definition aims to be inclusive, the field of innovation and sustainability as well as the related terminology is still developing.

\subsection{Framework for the study}

First, the interview questions were formulated according to the basic ideology of backcasting, that is, the desirable future states and required pathways/steps were asked about from the respondents. In the interviews, respondents were encouraged to consider the ideal future state for their own business, and then the whole the Finnish FBS. Secondly, this interview material will be interpreted and discussed in relation to sustainable business model literature, particularly the archetypes presented by Bocken et al. (2014) in this manuscript. The findings are further reflected from the perspective of strategic foresight. 


\section{Data and methods}

\subsection{Sample and approach}

The research methodology applied in this study has been described earlier (however, not including details on the backcasting process) in Näyhä $(2019,2020)$, because the data for these studies were gathered from the same interviews. The data consist of semi-structured thematic interviews (conducted in spring 2017) with 18 company managers from various FBS firms and companies from interfacing sectors, all of which have operations in Finland. The participating companies were all involved in the development of new products and services from wood-based raw material as either supplements to their portfolio or as main products. The aim was to include as many different types of organizations as possible. The firms varied in business models, product portfolio, maturity, size, growth plans, market orientation, the role of new products versus old products in their portfolio and exchanges (business-tobusiness/business-to-consumers). In addition to traditional FBS products, there were various new wood-based products and services under strategic planning, $R \& D$, commercialization and/or production. These included biofuels, bioenergy, biochemicals, biocomposites, textile fibers, biomedicines, healthcare products, food industry additives, new types of construction and building materials, interior design products, and packaging materials and solutions. The firms varied from large-scale, traditional, and mature FBS companies to SMEs and start-up firms. Most of the firms categorized themselves primarily as bioeconomy companies, and many considered themselves as both bioeconomy and circular economy firms. (For more details on company views on the bioeconomy and circular economy, see Näyhä, 2019.)

The respondents were given the key research topics during the initial inquiry regarding the interview, so that they could determine if they were likely to possess adequate knowledge about the studied themes. In other words, a requirement for the interviewees was knowledge about the research topics. The personnel contacted held leading positions in the firms (e.g., CEO, chief development officer or chief sustainability officer).

As a whole, the interview questionnaire consisted of three parts: (1) business models and conceptualization; (2) role in the markets, competitiveness and resources; and (3) foreseeing the future. This manuscript is based mainly on the third part, and specific interview questions are presented in Appendix A.

In essence, the backcasting approach is designed to facilitate better understanding of different future alternatives that are seen as desirable (e.g. Dreborg, 1996; Quist et al. 2006; Bibri, 2018). This was also the overall goal in this study. In the interviews, the key idea of a backcasting approach was loosely followed, that is, company representatives were asked to define desirable future states first for their own businesses, and second for the whole Finnish forest-based sector in 2030. The interviewees were also asked to define the required actions for attaining the desirable future states they described. The study did not follow any particular backcasting framework. The respondents were not given any more specific guidelines, meaning they were able to freely discuss various viewpoints and details when describing the future states. During the interviews, the respondents often discussed their future goals in 
relation to other questions, and these perspectives were also included when they were assessed to be relevant for the final outcome.

More accurately, the starting point here was that the participating companies pursue a shared future goal, namely "success in the forest-based circular bioeconomy" (indicated by y-axes in figures 1 and 2), which respondents indicated as their overarching vision throughout the interviews. Further, desirable attributes common for all desirable future states (triangles in figures 1 and 2) were identified. Different desirable future states (indicated as numbered boxes in figures 1 and 2) were created, all of which fulfilling the overarching goal of being successful forest-based circular bioeconomy actor (The exception is state 2, presented in box 2 , figure 2. Please see the explanation for this in section 4.3). This study bears a resemblance with numerous other studies in the regard that several alternative future states ("future images/scenarios" in Svenfelt et al. 2011; "future visions" in Quist et al. 2011, case MSL; "end states"/finalized scenarios" in Heinonen and Lauttamäki, 2012 and "visions" in CarlssonKanyama et al. 2013) were formulated, all fulfilling certain goals and criteria, which present a solution to a prevailing challenge. The focus in this study was more on the creation and visualization of desirable future states companies would like to attain than on detailed descriptions of the transition steps. The drivers in the operational environment and organizational resources for the transition were discussed at length in parts one and two of the interview, and they have been presented in Näyhä (2020) in detail, which was the reason for including only an outline of the key transition steps only in this paper. In addition, it was not appropriate nor possible to include a follow-up or implementation agenda (which are often part of the backcasting framework) in this study. Some perspectives on implementation are, however, discussed in section 5 . In addition, it is important to bear in mind that different backcasting studies often apply varying terminology, and there is also plenty of variation in expressions and different understandings related to labelling studies as discussed in section 2.2 (see also e.g. Vergragt and Quist, 2011; Wangel, 2011; Bibri, 2018). Therefore, categorizing the certain backcasting study under one unambiguous label is not often possible or reasonable, as this author believes is the case here.

As described earlier in section 2.2, backcasting has plenty of potential as a strategy management tool and it has been applied in many fields. However, its invocation is rare in business contexts. This researcher believed that the backcasting approach could be useful in provoking future-oriented thinking among the company representatives, and thus give interesting information on the transition and future goals of FBS companies as well as on the potential of applying foresight in strategic management in the companies. These were the main reasons why backcasting was chosen to be applied in this study. In addition (as an extension to the actual scientific goal), the researcher believed that participating in this study and practicing foresight/backcasting-oriented thinking in the interviews, would make company practitioners aware about backcasting approach, and its application potential in their own strategy processes in future.

However, it is apparent that an interview setting does not correspond with a real-life strategic management process in the companies. This researcher also fully understands that the 
backcasting process carried out in the way done in this study, namely by interviewing company representatives, has obvious defects. Backcasting processes usually contain several steps, phases and various stakeholders are also often involved, and they combine different methods in order to capture the full complexity of the phenomenon being studied (as has been done, for example, in these recent backcasting studies from the forest-based sector: de Bruin et al., 2017; Hurmekoski et al. 2018; Sandström et al., 2020). In this study, data were gathered in one phase without involving stakeholders in the process. Despite the obvious shortcomings in the methodology, the thematic interview format allowed interviewees plenty of freedom to elaborate their views and opinions during the interviews about the future visions and related strategic actions. The respondents talked freely not only in the context of specific foresight questions in part 3 , but also throughout the interviews.

\subsection{Data analysis}

The data were approached mainly inductively (see Patton, 2002, p. 56; Thomas, 2006, "general inductive analysis"), meaning, for example, that the coding (see also "open coding", in Strauss and Corbin, 1998; Eriksson and Kovalainen, 2008) was not restricted to the predetermined themes or theoretical frameworks. An inductive approach was seen as the best alternative for studying the ongoing novel transition phenomenon in the FBS companies. However, it is important to understand in this context that a purely inductive approach is not possible in any research, because it would require that the researcher has no preconceptions on the studied topic (see Patton, 2002; Eriksson and Kovalainen, 2008). Overall, researchers often apply both induction and deduction in different phases in their studies, as is the case in the current study (sometimes referring to "abduction" as an approach to combine induction and deduction in one research project; Eriksson and Kovalainen, 2008).

The data were examined using thematic analysis (Braun and Clarke, 2006; Guest et al., 2012). The interviews were transcribed and ATLAS.ti was used as an analysis tool. The analysis loosely followed the step-by-step guide presented by Braun and Clarke (2006). Basic rules for open coding created by Eriksson and Kovalainen (2008, p. 164, modified from Strauss, 1990; Strauss and Corbin, 1998) were also applied during the analysis. The interviews were first read through to obtain an overall understanding of the contents (similarly to open coding). Second, the preliminary themes (note that categories are used interchangeably with codes in this study) were coded in the data that were evaluated as being essential for achieving the research goal (i.e., understanding the theme is similar to the description presented by Braun and Clarke (2006, p. 10): "A theme captures something important about the data in relation to the research question..."). Third, contents and coded themes were reevaluated and more detailed sub-codes were assigned if needed. Then the codes were reorganized to compose broader-level main themes. At the end, data and created codes and themes were reevaluated again, and possible supplementary information was searched for from the data in order to establish a final understanding and interpretations.

In part 3 ("Foreseeing the future", where the interview questions were structured to support a backcasting approach), the analysis followed the open coding principles presented above. Overarching desired attributes for the future states (i.e. criteria for all the future states), the components for each desirable state and the elements for needed pathways were coded and, 
subsequently, these codes/themes were further processed and reorganized. Finally, in the context of company-specific views the different opinions (sub-codes) from the respondents were categorized to form three final future states (broader-level main themes). In the context of the entire FBS, two final future states were formed. In other words, each individual future state retains and reflects the opinions of those respondents who think alike. However, some of the respondents contributed many desirable states, and some of them only one. Due to the chosen qualitative approach, quantitative content analysis was not conducted. Nevertheless, when there has been a clear difference in the views between the large companies and small companies or when any other identified feature of the companies has clearly influenced opinion, it has been discussed in the manuscript so as not to reveal the identity of the company/respondent.

In this study, the trustworthiness (see also Guba and Lincoln, 1985) of the study has been sought by ensuring that the approach, sample and interview themes were chosen, structured and analyzed in a way that there is concordance between them. In this manner, the overall aim is to produce as full an understanding as possible of the studied issues (see also "verification strategies" in Morse et al., 2002, p. 18; in Sousa, 2014, Fig. 1), and thereby arrive at reliable findings (see also Silverman, 2005, p. 242). To strengthen the validity of the research, critical thinking during the data analysis (coding) was supported by the constant comparative method and deviant case analysis (Silverman, 2005). The first method refers to the practice that the analysis was started with a small part of the data and by defining preliminary themes and concepts, then it was continued by expanding the analyzed data corpus (i.e., by including more interviews). Second, "deviant case analysis" refers to an approach in which anomalous and divergent opinions were also seen as important in creating a comprehensive understanding. Modifying preliminary classifications (themes) was part of the process. Data were also interpreted based on various perspectives (see "theoretical triangulation" in Denzin, 1970). In addition, the readers of this study are offered material for evaluating its quality, such as the detailed description of the research process and numerous quotes from the interviews (Appendix B).

\section{Results}

\subsection{Transition in Finnish FBS companies towards sustainable and circular bioeconomy}

In order to frame the future states and pathways presented in this study, this section briefly casts a light on respondents' views on the transition and their role as transition actors in general. The issues presented in this section (4.1) have been described and discussed in more detail in earlier publications (see Näyhä 2019, 2020).

The respondents believed that forest-based businesses can respond to many current challenges in our society, and thus facilitate sustainability transition. The mitigation of climate change was at the core but also problems such as resource scarcity and replacing fossil-based products through forest-based materials and products were seen to be important. It was also pointed out that resource scarcity puts pressure on people to reconsider their consumption habits, and this will affect also the demand for forest-based products. Overall, the 
sustainability discussion focused largely on biomass sustainability -the carbon stocks of Finnish forests in particular - and less emphasis was put on biodiversity losses of forest ecosystems.

A successful transition management in the companies requires a thorough understanding of what is required, accepted and valued by their stakeholders, markets and society. This brings stakeholder dialogue to the fore, as well as the need for new ways of establishing this interaction. Concerns were raised that firms often have difficulties understanding the needs and mindsets of future generations.

The firms strongly believed that there will be demand for bio-based products and materials in the future, despite the admitted difficulty to foresee changes in the global economy. Overall, demand and markets guide companies in their decisions about practices and offerings, and the interviewees regularly mentioned the importance of customers and their perspectives in relation to these issues. The companies emphasized that they need to focus more on the unmet needs of customers, while at the same time fulfill the sustainability goals set by all their stakeholders.

Despite the many unanimous views on the transition among FBS firms, it should be remembered that forest-based circular bioeconomy actors form a diverse network of companies with a range of views. There is no unanimous opinion of the most optimal and sustainable uses of forest-based resource. In particular, the respondents whose businesses require small volumes of biomass and/or who are looking to produce more value-added products criticized the firms requiring large volumes of raw material for "bulk products", that is, high volume products with less value.

Overall, the core standpoint is that companies define themselves as bio- and circular economy actors, forerunners and innovators with plenty of unutilized potential in the future. Sustainability is seen to be in a key position in their business models. The common strength is the location in Finland, which has a long history and strong expertise in forest utilization. The company representatives also highlight their expertise and leading position in their own specific field. This means that companies positioned themselves to many other organizational/market categories in addition to the bio/circular economy. In the responses the interviewees also mentioned that they can focus on different competencies and market positions depending on the circumstances and contexts in which they are operating.

\subsection{Desirable future states for Finnish FBS companies}

The company representatives were asked first to define desirable future state for their own businesses ("Please describe the desirable future state for your own business in 2030; What kind of steps and actions are needed to get there?"). Based on the data, three different ideal future states could be distinguished for the forest-based sector companies (Figure 1). These states can be defined as follows: (1) traditional production as enabler; (2) new large-scale facilities with high volume production; and (3) new SMEs with high value-added, small volume production. In the first desirable future state, traditional production has a major role in the 
FBS, and it creates a basis for new business development through securing funding for R\&D and thus enabling product portfolios to be expanded.

\section{quotation 1,2}

Both the second and third states emphasize the key role of new types of facilities and businesses in the FBS; either with high volume production in large-scale facilities (state 2), or small volume production with high value in SMEs (or in collaboration with SMEs) (state 3).

\section{quotations 3,4}

In all the desirable future states, expanded business and largely increased profits are desirable attributes, and desirable states will often be based on new products and services, thereby creating more versatile product portfolios. Desirable future states are also characterized by well-recognized company status with established market position.

\section{quotation 5}

In addition, the respondents defined sustainability as one of the attributes of desirable states, but they gave much less emphasis to it compared to the issues related to expanded businesses and versatile product portfolios.

According to the respondents, the desirable future states can be attained most of all through strong knowledge in the firms, innovativeness and innovations, and a commitment to hard work.

\section{quotations 6,7}

Aiming for specialization and a high degree of upgrading are important actions. Moreover, the fulfillment of stakeholder demands and creation of partnerships with other companies are needed to attain desirable future states, though the respondents put notably less emphasis on these actions compared to the knowhow and committed working attitude within the firms (see also Näyhä 2020).

\section{quotations 8,9}

It is noteworthy that, as discussed in details in Näyhä (2020), companies highlight various intangible and human resources as necessary for successful transition. Without an agile and encouraging organizational culture which is supported by non-hierarchical top-management, multi-skilled teams and inspiring employees, the needed transition actions cannot be taken. The availability of wood-based raw material and educated people has traditionally formed the backbone of the Finnish forest-based industries, and this study understandably highlights their continuing relevance in the future.

Overall, it seems that state one is emphasized by large, mature companies. Large company representatives tend to stress more than do those from smaller firms that traditional businesses guarantee income, traditional products are still needed, and traditional businesses 
make R\&D and new businesses possible in the firms. The respondents also agreed that the flexibility and agility needed in restructuring the business models can be more challenging for large companies than it is for small-scale organizations due to the large initial investments and high fixed costs of large companies (see also Näyhä, 2020). States two and three describe the ideal futures particularly for market entrants and/or smaller companies, but also reflects mature companies' endeavors towards enlarged portfolios.

Figure 1. Desirable future states and related key actions of the Finnish FBS firms (framework modified from Steen and Åkerman, 1994; Phdungsilp 2011, p.709). (CBE is an abbreviation for "circular bioeconomy")

\subsection{Desirable and undesirable future states for the Finnish FBS as a whole}

In addition to the desirable future states for their own companies, the respondents were asked to describe the desirable future state and related steps for the entire FBS in Finland in 2030 (Figure 2). The Finnish FBS was seen to be a global pioneer and leading actor in the circular bioeconomy, which pays careful attention to sustainability and environmental issues also on a global scale. Sustainability related issues were clearly the most often mentioned attributes of this state. The ideal future state for the whole of the Finnish forest-based sector is thus named "sustainable and innovative Wood Valley of FBS". Specialization and innovative, high value-added products (production can be also outside Finland whereas planning and other high value-added activities would remain in Finland) are key parts of this desirable future state. Efficient utilization of natural resources was seen as the most important means to achieve the desirable sustainable future state. Attaining the desirable future state also requires the creation of high team spirit and trust between actors in the FBS hubs. Overall, the growth in the FBS is based on new actors, products and services, which also accelerate the transformation of the traditional businesses (see also Näyhä 2020).

\section{Quotations 10-17}

Although the respondents were not asked about the undesirable future state of the Finnish FBS (nor is this type of question usually part of the backcasting process), many of the respondents wanted to share their views on fears and threats regarding the future of the FBS. The respondents were afraid that uncertainty in the global business environment could create significant challenges. They emphasized that decreased demand for pulp and paper could cause financial challenges for the firms, which means that they would not have adequate resources for R\&D. This, in turn, could lead to stagnation or the disappearance of many (largescale) facilities because they cannot renew their businesses. Interviewees also stated that Finland cannot succeed without collaboration between companies and joining forces to commercialize and market top-of-the line products.

\section{Quotations 18}

Figure 2. Desirable and undesirable future states for the entire Finnish FBS (framework modified from Steen and Åkerman, 1994; Phdungsilp 2011, p.709). 


\subsection{Does the Finnish FBS need future visions?}

In addition to describing the desirable future states, the interviewees were also asked about their views on the clarity of the visions of FBS actors ("Do you believe that the desirable future state/vision is clear for the forest-based sector actors in Finland?"). The respondents presented a diverse range of opinions and views on this question.

There were interviewees who believed that global and EU-level goals and sustainability aims guide - often sufficiently - the companies' future actions. Moreover, concrete, already materialized businesses fulfilling these goals function as examples and provide inspiration to the other actors.

On the other hand, some of the respondents pointed out that the authorities lack clear visions for the development of FBS and many sustainability-related guidelines, which creates difficulties for the companies. It was believed that this lack causes challenges, for example, when planning the use of forest resources. In addition, it was brought up that the Finnish bioeconomy strategy does not consider concrete, everyday practices and challenges. Moreover, the lack of a vision for Finnish society as a whole was also noted.

\section{Quotation 19}

On the contrary, there were respondents who believed that there is no need for a common vision for the FBS. Every company makes their own decisions and steers their businesses by choosing the alternatives that are best for them. Some of the respondents emphasized that the market economy and its free functioning should not be disturbed by governmental interference. The companies should be allowed to operate independently, yet they should also aim for collaboration with other firms.

\section{Quotation 20}

Some respondents argued that many FBS companies lack visions due to the existing turning point in the FBS, and future visions should be defined more distinctively. A lack of future visions was seen problematic particularly for the small-scale actors. However, it is noteworthy that all interviewees argued that their own company has a clear vision, and pointed out that the lack of visions are problematic for other FBS firms.

\section{Quotations 21, 22}

\section{Discussion and conclusions}

This study explores the transition of Finnish forest-based sector companies to new business models. More specifically, the research concentrates on the desirable future views of the FBS company managers, on how they define ideal future states for their companies as well as for the Finnish FBS as whole by 2030. The goal is to shed light on the future-oriented thinking and 
mindset of the FBS firms, and reflect on the findings from the perspectives of sustainable business models and of strategic foresight research. In addition to presenting key results and reflecting on these findings in light of relevant theoretical perspectives, this section summarizes the main themes identified by the three connected articles published by this author, each of which explores different dimensions in the FBS transition. ${ }^{3}$

The attempts at growth and the appearance of new products characterize the companyspecific desirable future states. In these future states, expanded businesses will be based on strong knowledge and innovations. Sustainability attained through resource efficiency and collaboration creates a strong basis for the desirable future state of the whole FBS as a sustainable and innovative Wood Valley. This future state indicates that the current leading role in the forest-based businesses will not be relinquished - on the contrary - the Finnish FBS comprises a successful and sustainable hub where environmental perspectives are carefully considered.

The vital role of sustainability and sustainable business strategies were highlighted throughout the interviews (see also Näyhä, 2019, 2020). It is noteworthy, however, that desirable future states for individual companies and the FBS as a whole differ clearly in their emphasis on sustainability. When the respondents described attributes for the companyspecific future states, sustainability was rarely mentioned, if at all, whereas in the context of a desirable future state for the FBS as a whole, sustainability was the most frequently mentioned issue. This outcome is rather surprising and when reflecting on the finding further, one can ask what this phenomenon says: do companies see their own operations and practices as more sustainable than those of other companies? Or is sustainability of secondary importance compared to other issues in company management? Can this be an indication that sustainability is viewed more as a shared responsibility or as the responsibility of others?

Attempts to grow businesses and being a global forerunner will likely lead to the increased utilization of biomass, which inevitably conflicts with the sustainability vision. It would be essential to search for a balanced solution to combine the goals of growth and sustainability. This discussion is connected to the debate on the role of the bulk products versus high value added products in the FBS of the future, since this issue will have a crucial effect on wood biomass utilization. Developing sustainable, highly specialized, higher value-added products, in turn, requires innovations and specialization as well as resource efficient use of materials as clearly indicated in the future states (see also Näyhä, 2019, 2020). Related to this reasoning, a study conducted by Pellervo Economic Research PTT indicates that the utilization of wood will increase strongly in Finland by 2035 . However, wood biomass will be utilized more in lower value added production than it is currently. This means that use of wood will increase relatively more than the subsequent value added and output. In order to change

\footnotetext{
${ }^{3}$ Two of the articles have already been published (Näyhä, 2019, 2020). This current manuscript is the third and last one to utilize the data from the same interviews conducted among Finnish FBS companies in 2017. The different parts of the interviews were analyzed for each article: business models and conceptualization (Näyhä, 2019); role in the markets, competitiveness and resources (Näyhä, 2020); and foreseeing the future (current study).
} 
this situation, PTT's study emphasizes the importance of resources aimed at research and development (Hietala and Huovari, 2017).

When the findings are analyzed from the perspective of sustainable business models, particularly that of Bocken et al.'s (2014) sustainable business model archetypes, it can be seen that business models in the FBS sector have several inherent connections with the archetypes in the technological grouping (see section 2.3.1): resource/material efficiency, circular economy principles, using renewable resources (as substitutes for fossil-based materials). As noted in section 4.3 , the sector-specific desirable future state emphasizes environmental sustainability and resource efficiency (indicating the material and energy efficiency archetype). In the company-specific desirable future states (see section 4.2), business models relate mostly to the archetype of developing scale-up solutions, including "collaborative approaches" (Bocken et al. 2014, p. 48). Overall, it can be seen that future FBS business models aim to extend their scope in many ways over the conventional business model perspective, which is more or less planned around a value proposition for customers (see Schaltegger et al. 2016).

Furthermore, elements of IfS - the introduction of products that benefit the environment and society - (Bocken et al. 2019, p. 6) are a distinctive part of new FBS business models. However, it appears that one of the biggest challenges for companies currently is to fulfill the requirement for indicating environmental or social benefits by "traceable comparative analysis" (Bocken et al. 2019, p. 6). In other words, measuring and communicating actual impacts of sustainable business models and innovations transparently is often difficult for companies, because practices and tools for these are lacking (see also the end of this section). The development of the measurement tools should be done in collaboration with private sector actors and academics (as well as by utilizing the expertise of other stakeholders when needed). Without these kinds of tools and practices, efficient stakeholder communication and responding to stakeholder demands - indicated as an important pathway towards desirable future states in this study - cannot be accomplished.

Numerous studies emphasize the importance of corporate foresight for strategic planning and the long-term success of the companies. Likewise, many of them indicate a lack of systematic interrogation of foresight in strategy and innovation processes in practice (e.g. Vecchiato and Roveda, 2010; Peter and Jarrat, 2015; Ruff, 2015). Rhisiart et al. (2015), for example, proposes that firms should invest in rich scenario processes which can develop the capabilities of managers to sense changes and develop dynamic capabilities. Bootz et al. (2019) notes that foresight activities can promote collective forms of learning in companies. Thorén and Vendel (2018) highlight that the challenges of management in a highly uncertain business environment and the limitations of popular strategizing tools create the need for approaches which could inspire effective discussions on distant futures and support strategy making. Backcasting is seen to meet these challenges well.

In this study the respondents presented various views on the significance of future visions for the FBS and the companies working in the sector. Many respondents stated that thinking about future states in 10 years from now is challenging. This view was indicated either directly or the researcher could draw this conclusion based on how the respondents approached the 
issue and answered the questions. Interestingly, respondents often commented that their own companies have clear future visions, whereas there are other companies in the sector that lack vision. Even though the respondents were not asked specific questions about applying (systematic) foresight practices in their own companies or respondents' familiarity with backcasting approach, it appeared that many of the respondents were not familiar with such practices. As pointed out in section 2.2, empirical literature with case descriptions on backcasting applications is largely lacking. Thus, it is likely that many managers are not aware of such methods and/or do not identify the advantages they can offer for the strategy process. Further, it may require courage and determination from leaders to direct companies toward broadly defined future states (as is often the case in backcasting), which, in turn, urges agility and flexibility in strategies and strategic management (see also Thorén and Vendel, 2018). In addition, it is often not understood that the aim in foresight is not to produce exact predictions of the future. Instead, foresight can offer information on different future alternatives and thus help firms to prepare for future challenges (see e.g. Vecchiato, 2015). Besides this reasoning (when looking at the available literature), it remains unclear why backcasting is not more widely applied in the business context.

It is noteworthy - especially in light of the global coronavirus disease pandemic of 2020 - that the future considerations of the firms did not include the potential occurrence of sudden, unpredictable events (so-called black swans), which can have major impacts on societies, including various businesses. The COVID-19 outbreak is an example of such an event with a huge impact on economies, and its overall effect remains unknowable. At this point, it is impossible to evaluate what this outbreak means for the issues explored in this study. It is certain, however, that all the businesses and companies explored in this study will be affected in one way or another.

When the period up to 2030 is considered, this author believes that visualizations of the different future states will all be realized to some extent, meaning that various elements presented in the desirable futures are part of the future of the FBS in one form or another. It appears that FBS firms' future business models are more multifold than the current ones are, with new (often more value-added) products and more versatile product portfolios. There will be a wider range of different companies in the FBS. It is also possible that in ten years' time the elements presented in the undesirable future state will be realized as well, at least to some extent. When the key findings and conclusions of the three manuscripts ${ }^{3}$ exploring the FBS transition are integrated, it becomes clear that the sustainability of business models and a shared understanding of them with and between the FBS stakeholders are the most distinct themes in the transition. In other words, in future business models companies will pursue sustainable value creation in an even more built-in manner. Related to these it can be argued that there should be collaborative and participative, future-oriented efforts for discourse and development work (see also e.g. Svenfelt et al. 2011). This also calls for open foresight or networked foresight, where firms can look into the future in collaboration (see also Winer and Boer, 2019; Heger and Boman, 2015; Daheim and Uerz, 2008). By integrating foresight in their management, companies can develop their dynamic capabilities into strategic agility, which in turn helps them to attain long-term success (see also Vecchiato, 2015; Rhisiart et al., 2015). Importantly, there should also be effective tools and ways 
available to detect, measure and evaluate first if there is a gap between strategy formulation and implementation in companies, and second, the impacts of implemented business models on sustainability. Business models can have a crucial role in attaining systemic change towards a more sustainable society, but only if they have impact in actual practice.

\section{Limitations and future studies}

One of the key limitations of this study is that the backcasting process was conducted only through interviews (see more detailed discussion on this in section 3.1). In addition, a wider participative approach with stakeholder dialogue and views (see e.g. Quist et al. 2011) is lacking in the backcasting process. This means that the desirable states and needed pathways for action are created by the FBS companies only. As discussed earlier in this paper, interactivity and dialogue between the stakeholders during the backcasting process enables the development of versatile views and pathways. In the context of FBS development, it would also be important to build visions through a variety of societal perspectives and by presenting different, possibly more in-depth viewpoints. This kind of approach could facilitate common understanding and reduce the strongly polarized discussions in Finland, thus indicating directions for future studies. The time-scale used in the backcasting process was short, and longer periods are often recommended.

A further shortcoming of this study was that the respondents were not asked any specific questions on applying backcasting or some other foresight practices in their own companies. This means the researcher had no knowledge on the current state of the company foresight practices used (if any) in the companies. This type of information would have been useful when reflecting on the outcomes of the backcasting process. Overall, there are only a few reports available which describe how foresight is actually integrated into the innovation and strategy processes of companies (Ruff, 2015, see also section 2.2). There is a clear need for more research on this integration in the FBS as well as in other sectors.

\section{References}

Bas, E., Guillo, M., 2015. Participatory foresight for social innovation. FLUX-3D method (Forward Looking User Experience), a tool for evaluating innovations.

Baumgartner, J., Rauter, R., 2017. Strategic perspectives of corporate sustainability management to develop a sustainable organization. Journal of Cleaner Production 140, 8192.

Bell, W. 2003, Foundations of Futures Studies. Volume 1. History, Purposes and Knowledge. Transaction Publishers, 365p.

Bibri, S.E. 2018. Backcasting in futures studies: a synthesized scholarly and planning approach to strategic smart sustainable city development. European Journal of Futures Research, 6, 127. 
Bidmon, C.M. Knab, S. F. 2018. The three roles of business models in societal transitions: New linkages between business model and transition research, Journal of Cleaner Production, 178, 9003-916.

Bishop, P., Hines, A. (Eds.) 2007. Thinking About the Future; Guidelines for Strategic Foresight. Social Technologies, Houston.

Bocken, N., Ritala, P., Albareda, L., Verburg, R. 2019. Introduction: Innovation for Sustainability. in: Bocken, N., Ritala, P., Albareda, L., Verburg (Eds.), Innovation for Sustainability Business Transformations Towards a Better World, pp. 1-16.

Bocken, N.M.P., Short, S., Rana, P., Evans, S., 2014. A literature and practice re-view to develop sustainable business model archetypes. Journal of Cleaner Production 65, 42-56.

Boons, F. and Lüdeke-Freund, F. 2013. Business models for sustainable innovation: state-ofthe-art and steps towards a research agenda. Journal of Cleaner Production, 45, 9-19.

Bootz, J-P, Duranceb, P., Monti, R. 2019. Foresight and knowledge management. New developments in theory and practice. Technological Forecasting and Social Change, 140: 8083.

Berger, G., Bourbon-Busset, J.d., Massé, P., 2008. De la prospective: Textes fondamentauxde la prospective fancaise 1955-1966. L'Harmattan, Paris.

Braun, V. and Clarke, V., 2006. Using thematic analysis in psychology. Qualitative Research in Psychology, Vol. 3, No. 2. pp. 77-101.

de Bruin, J. O., Kok, K., Hoogstra-Klein, M.A. 2017. Exploring the potential of combining participative backcasting and exploratory scenarios for robust strategies: Insights from the Dutch forest sector. Forest Policy and Economics, Vol. 85, Part 2, pp. 269-282.

Broman, G. I., Robert, K-H. 2017. A framework for strategic sustainable development. Journal of Cleaner Production, Vol. 140, pp. 17-31.

Carlsson-Kanyama, A., Carlsen, H., Dreborg, K-H. 2013. Barriers in municipal climate change adaptation: Results from case studies using backcasting. Futures 49: 9-21.

Carlsson-Kanyama A., Dreborg, K.H., Mollb H.C., Padovan D. 2008. Participative backcasting: a tool for involving stakeholders in local sustainability planning. Futures $40(1), 34-46$

Chesbrough, H. W. 2003. Open innovation. The New Imperative for Creating and Profiting for Technology. Harvaed Business Press, p. 227.

Daheim, C., Uerz, G. 2008. Corporate foresight in Europe: from trend based logics to open foresight, Technology Analysis \& Strategic Management, 20, pp. 321-336, DOI: 10.1080/09537320802000047

D’Amato, D., Veijonaho, S., Toppinen, A. 2019. Towards Sustainability: Forest-based circular bioeconomy business models in Finnish SMEs. Forest Policy and Economics (in press). 
Destatte, P. 2010. Foresight: A major tool in tackling sustainable development. Technological Forecasting and Social Change, 77, 1575-1587.

Dreborg, K. H. 1996. Essence of Backcasting. Futures 28, 813-828.

Dyllick, T., Hockerts, K. 2002. Beyond the business case for corporate sustainability. Business Strategy and the Environment 11, pp. 130-141.

Engert, S., Baumgartner, R.J. (2016). Corporate sustainability strategy - bridging the gap between formulation and implementation. Journal of Cleaner Production, 113, 822-834.

Eriksson, P. and Kovalainen, A., 2008. Qualitative Methods in Business Research. Sage Publications, London.

Guba, E.G. and Lincoln, Y. S., 1985. Naturalistic inquiry, Beverly Hills: Sage, 1985.

Guest, G., MacQueen, K., Namey, E., 2012. Applied Thematic Analysis, Sage Publications, Thousands Oaks, California.

The Global Foresight Group, 2019. Availabe at http://theglobalforesightgroup.com/whyforesight. Accessed September 10, 2019.

Heger, T., Boman, M. 2015. Networked foresight-The case of EIT ICT Labs. Technological Forecasring and Social Change 101: 147-164.

Heinonen, S., Lauttamäki, V. 2012. Backcasting scenarios for Finland 2050 of low emissions. Foresight, 14, 304-315.

Hetemäki, L., Hanewinkel, M., Muys, B., Ollikainen, M., Palahí, M., Trasobares, A., 2017. Leading the way to a European circular bioeconomy strategy. From Science to Policy 5. European Forest Institute. http://www.efi.int/files/attachments/publications/efi_fstp_5_2017.pdf, Ac-cessed date April 17, 2018.

Hietala, J., Huovari, J. Economic Impacts and Outlook of the Finnish Wood-based Bioeconomy. PTT Working Papers 184 PTT Working Papers 184. Pellervo Economic Research PTT, Helsinki 2017. (in Finnish)

Hiilamo, E.A. 2019. Helsingin Sanomat, 5.10.2019. (article in newspaper) https://www.hs.fi/politiikka/art-2000006262558.html

Hines, A. and Gold, J. 2015. An organizational futurist role for integrating foresight into corporations. Technological Forecasting and Social Change. Vol. 101, pp. 99-111.Hurmekoski, E., Johnsson, R., Korhonen, J., Jänis, J., Mäkinen, M., Leskinen, P., Hetemäki, L. 2018. Diversification of the forest industries: role of new wood-based products. Canadian Journal of Forest Research, 48(12) 1417-1432.

Holmberg J., Robèrt K.H. 2000. Backcasting from non-overlapping sustainability principles: a framework for strategic planning. Int J Sustain Dev World Ecol 74, 291-308. 
Hurmekoski, E., Pykäläinen, J. and Hetemäki, L. 2018. Long-term targets for green building: Explorative Delphi backcasting study on wood-frame multi-story construction in Finland. Journal of Cleaner Production,Vol. 172, pp. 3644-3654,

Höjer, M., Gullberg, A., Pettersson, R., 2011. Backcasting images of the future city - time and space for sustainable development in Stockholm. Technol. Forecast. Soc. Change 5, 819-834.

Kaivo-oja, J. 2016. Towards better participatory processes in technology foresight: How to link participatory foresight research to the methodological machinery of qualitative research and phenomenology? Futures 86, pp. 94-106.

Kauppinen, J., 2019. Monimuotoisuus, Livonia Print , Latvia (in Finnish).

Kishita, Y., McLellan, B.C., Giurco, D., Aoki, K., Yoshizawa,G., Handoh, I.C. 2017. Designing backcasting scenarios for resilient energy futures. Technological Forecasting \& Social Change 124, 114-125.Loorbach, D. and Wisjman, K. 2013. Business transition management: exploring a new role for business in sustainability transitions. Journal of Cleaner Production, 45, 20-28.

Lovins, A.B. 1977. Soft Energy Paths: Toward a Durable Peace, Friends of the Earth Int ernational/Ballinger Publishing Company, Cambridge, MA.

Martin, B. 2010. The origins of the concept of 'foresight' in science and technology: An insider's perspective. Technological Forecasting and Social Change, 77, 1438-1447.

Miles, I. 2010. The development of technology foresight: A review. Technological Forecasting and Social Change, 77, 1448-1456.

Ministry of Employment and Economy of Finland, 2014. Finnish Bioeconomy strategy. http://biotalous.fi/wp-content/uploads/2014/08/The Finnish BE Strategy 110620141.pdf

Morse, J.M., Barret, M., Mayan, M., Olson, K., Spiers, J., 2002. Verification Strategies for Establishing Reliability and Validity in Qualitative Research. International Journal of Qualitative Methods 1, 13-21.

Näyhä, A., Pelli, P., Hetemäki, L., 2014. New products outlook. In Hetemäki, L. (Ed.), Future of the European Forest-Based Sector: Structural Changes Toward BE. What Science Can Tell Us 6, European Forest Institute.

Näyhä, A., Pelli, P., Hetemäki, L., 2015. Services in the forest-based sector: Unexplored futures. Foresight 17, 378-398.

Näyhä, A. (2019). Transition in the Finnish forest-based sector: Company perspectives on the bioeconomy, circular economy and sustainability. Journal of Cleaner Production, Vol. 209, pp. 1294-1306.

Näyhä, A. (2020). Finnish forest-based companies in transition to the circular bioeconomy: Drivers, organizational resources and innovations. Journal of Forest Policy and Economics, Vol. 110, pp. 1-14.

Ollikainen, M., 2014. Forestry in Bioeconomy: Smart green growth for the humankind. Scandinavian Journal of Forest Research 29, 360-366. 
Ollikainen, M. and Seppälä, J. 2019. Metsien käytöstä pitää saada kokonaisnäkemys. Mielipide/Vieraskynä Helsingin Sanomat 20.11.2019. Available at https://www.hs.fi/mielipide/art-2000006314010.html. Accessed 22.11.2019. (In Finnish)

Patton, M.Q., 2002. Qualitative Research \& Evaluation methods. 3rd Edition, Sage publications, Thousands Oak, CA.

Peter, M.K, Jarrat, D.G. 2015. The practice pf foresight in long-term planning. Technological Forecasting and Social Change, 101, 49-61.

Phdungsilp, A. 2011. Futures studies' backcasting method used for strategic sustainable city planning. Futures 43 (7), 707-714.

Quist, J., Thissen, W., Vergragt, P.J., 2011. The impact and spin-off of participatory backcasting: From vision to niche. Technological Forecasting \& Social Change 78: 883-897.

Quist, J. 2009. Stakeholder and user involvement in backcasting and how this influences follow-up and spin-off. Faculty of Technology, Policy and Management, Delft University of Technology

Quist, J. 2007. Backcasting for a sustainable future: the impact after ten years, Eburon, Delft NL.

Quist, J. and Vergragt, P. 2006. Past and future of backcasting: The shift to stakeholder participation and a proposal for a methodological framework. Futures 38 (9), 1027-1045.

Rauter, R., Jonker, J., Baumgartner, J., 2017. Going one's own way: Drivers in developing business models for sustainability. Journal of Cleaner Production 140, 144-154.

Rhisiart, M., Miller, R., Brooks, S. 2015. Learning to use the future: developing foresight capabilities through scenario process. Technological Forecasting and Social Change, 101:124133.

Rinta-Jouppi, A. 2019. Helsingin Sanomat 6.6. 2019. (article in newspaper) https://www.hs.fi/politiikka/art-2000006133932.html. Accessed 4.11.2019.

Robinson, J. B. 1982. Energy backcasting: a proposed method of policy analysis. Energy Policy 10, 337-344.

Robinson, J. 2003. Future subjunctive: backcasting as social learning, Futures 35, 839-856.

Robinson, J., Burch, S., Talwar, S., O'shea, M., Walsh, M. 2011. Envisioning sustainability: Recent progress in the use of participatory backcasting approaches for sustainability research. Technological Forecasting and Social Change, 78, pp. 756-768.

Rohrbeck, R., Mahdjour, S., Knab, S, Frese, T. 2008. Benchmarking Report: Strategic Foresight in Multinational Companies, European Foresight Group, 22-24.

Rohrbeck, R., Battistella, C., Huizingh, E. 2015. Corporate foresight: An emerging field with a rich tradition. Technological Forecasting and Social Change, 101, 1-9. 
Rohrbeck, R., Kum, M.E., 2018. Corporate foresight and its impact on firm performance: A longitudinal analysis. Technological Forecasting and Social Change, 129, 105-116.

Rohrbeck, R., Etingue Kum, M., Jissink, T., Gordon, A.V. 2018. Corporate Foresight Benchmarking Report 2018: How Leading Firms Build a Superior Position in Markets of the Future. Available at SSRN: https://ssrn.com/abstract=3178562 or http://dx.doi.org/10.2139/ssrn.3178562

Ruff, F., 2015. The advanced role of corporate foresight in innovation and strategic management-Reflections on practical experiences from the automotive industry. Technological Forecasting and Social Change, 101:37-48.

Räinä, J. 2019. Biopesu. Kuinka biotaloudesta tuli uusi vetävämpi kutsumanimi selluteollisuudelle. in Jokiranta. A, Juntti, P., Ruohonen, A., Räinä, J. (Eds), Metsä meidän jälkeemme. Like Kustannus Oy, Helsinki. (in Finnish)

Sandström, C., Carlsson-Kanyama, A., Räty, R., Mossberg Sonnek, K., Nordström, E-A., Mossing, A., Nordin, A. 2020. Policy goals and instruments for achieving a desirable future forest: Experiences from backcasting with stakeholders in Sweden, Forest Policy and Economics, Vol: 111, pp. 2-10.

Sarasini, S. ad Linder, M. Integrating a business model perspective into transition theory: The example of new mobility services. Environmental Innovation and Societal Transitions, Vol. 27, pp. 16-31.

Sardar, Z., 2010. The Namesake: Futures; futures studies; futurology, futuristic; foresightWhat's in a name? Futures 42, 177-184.

Schaltegger, S., Hansen, E.G., Lüdeke-Friend, F. 2016. Business Models for Sustainability: Origins, Present Research and Future Avenues. Organization \& Environment, Vol. 29, pp.3-10.

Silverman, D., 2005. Doing Qualitative Research. 2nd Edition, Sage Publications, London

Slaughter, R. 2009. The state of playing the futures field: a metascanning overview. Foresight, $11,9$.

Sousa, D., 2014. Validation in Qualitative Research: General Aspects and Specifities of the Descriptive Phenomenological Method. Qualitative research in Psychology, 11, 211-227.

Sustainability Transitions Research Network, 2019. Research agenda. Available at https://transitionsnetwork.org/wpcontent/uploads/2016/09/STRN Research Agenda 2019c-2.pdf. Accessed 7.11.2019.

Svenfelt, Engström, R., Svane, O. 2011. Decreasing energy use in buildings by $50 \%$ by $2050-$ a backcasting study using stakeholder groups, Technological Forecasting and Social Change 78, 785-796.

Steen, P. and Åkerman, J. 1994. Syntes av studier över omställing av energy-och transportsystemen i Sverige. I Kilmatdelegationen (red.) Rapport från Klimatdelegationen: års rapport från Klimatdelegationen, Fritze, Stockholm, Sweden. 
Strauss, A., 1990. Qualitative Analysis for Social Scientists. New York, NY: Cam-bridge University Press.

Strauss, A. and Corbin, J., 1998. Basics of Qualitative Research. Thousand Oaks, CA.

Thomas, D. R. 2006. A General Inductive Approach for Analyzing Qualitative Evaluation Data, American Journal of Evaluation, 27, 237-246.

Thorén, K., Vendel, M. 2018. Backcasting as a strategic management tool for meeting VUCA challenges. Journal of Strategy and Management, 12: 298-312.

Toppinen, A., Pätäri, S., Tuppura, A., Jantunen, A., 2017. The European pulp and paper industry in transition to a bio-economy: A Delphi study. Futures 88, 1-14.

Upward, A., and Jones, P. 2016. An Ontology for Strongly Sustainable Business Models: Defining an Enterprise Framework Compatible With Natural and Social Science. Organization \& Environment, 29, 97-123

Vecchiato, R. and Roveda, C. 2010. Strategic foresight in corporate organizations: Handling the effect and response uncertainty of technology and social drivers of change. Technological Forecasting and Social Change, 77, 1527-1539.

Vecchiato, R., 2012. Environmental uncertainty, foresight and strategic decision making: An integrated study. Technological Forecasting and Social Change, 79, 436-447.

Vecchiato, R., 2015. Creating value through foresight: First mover advantages and strategic agility. Technological Forecasting and Social Change, 101, 25-36.

Vergragt, P. J. and Quist, J. 2011. Backcasting for sustainability: Introduction to the special issue. Technological Forecasting and Social Change, Vol. 78, No. 5, pp. 747-755.

Wangel, J., 2011. Exploring social structures and agency in backcasting studies for sustainable development. Technol. Forecast. Soc. Change 5, 872-882.

Wiener, M. 2017. Open foresight: The influence of organizational context. Creativity and Innovation management. Wiley DOI: 10.1111/caim.12238

Wiener, M. and Boer, H. 2019. Cultural perquisites for participating on open foresight. R\&D management.

Appendix A. Interview themes/questions

\section{PART 3 FORESEEING THE FUTURE}

1. Please describe the desirable future state/vision for your own business in 2030 . 
$=>$ What kind of steps and actions are needed to get there?

2. Please describe the desirable future vision/state for forest-based businesses in general in Finland in 2030.

$=>$ What kind of steps and actions are needed to get there?

3. Do you believe that the desirable future state/vision is clear for the FBS actors in Finland?

$=>$ Why/why not, what should be done?

Appendix B. Quotations

\begin{tabular}{|l|l|}
\hline Quotation number & Quotation \\
\hline 1 & $\begin{array}{l}\text { We still have modern facilities and } \\
\text { something has been renewed for sure. I } \\
\text { believe, however, that the basic product is } \\
\text { still the same, yet the product portfolio has } \\
\text { expanded to meet challenges and needs, } \\
\text { which will exist in the future. }\end{array}$ \\
\hline 2 & $\begin{array}{l}\text { Yes, it is possible [that higher value added } \\
\text { products will bring the bigger profits than } \\
\text { bulk product in future], but that won't } \\
\text { happen by 2030. Our basic industry will } \\
\text { bring the big share, and other industries } \\
\text { have difficulties to compete with that. } \\
\text { Maybe after 2030. }\end{array}$ \\
\hline 3 & $\begin{array}{l}\text { In 2030 we will probably have [new] } \\
\text { products which we don't even know about } \\
\text { today, which we are not even developing } \\
\text { yet. }\end{array}$ \\
\hline 5 & $\begin{array}{l}\text { I would think that the product portfolio } \\
\text { would expand in our organization, but I } \\
\text { can't right now predict anything very } \\
\text { extraordinary. }\end{array}$ \\
\hline 5 & $\begin{array}{l}\text { In 2030 we will likely be a well-recognized } \\
\text { brand in the field [...]. We will have } \\
\text { multiplied our sales compared to the } \\
\text { current situation. We will probably stay in } \\
\text { this field and try to establish our position. } \\
\text { Grow and establish the position. }\end{array}$ \\
\hline $\begin{array}{l}\text { I would count a lot on the availability of } \\
\text { ideas. }\end{array}$ \\
\hline $\begin{array}{l}\text { The knowledge in the organization has } \\
\text { further developed, for sure, and I believe } \\
\text { that working is more and more }\end{array}$ \\
\hline 5
\end{tabular}




\begin{tabular}{|c|c|}
\hline & $\begin{array}{l}\text { independent on every level [of the } \\
\text { organization]. }\end{array}$ \\
\hline 8 & $\begin{array}{l}\text { I assume that we have been moving } \\
\text { strongly towards partnerships. We have } \\
\text { partners. We don't necessarily buy and do } \\
\text { everything by ourselves but we can have } \\
\text { collaborating companies. }\end{array}$ \\
\hline 9 & $\begin{array}{l}\text { Our course of action has been changed in } \\
\text { the way that we listen to our customers } \\
\text { more, they are where ideas and the germs } \\
\text { of ideas come from. We are more likely to } \\
\text { respond and put into action the ideas, } \\
\text { which lead us to new paths and markets. }\end{array}$ \\
\hline 10 & $\begin{array}{l}\text { I would love to see that innovations created } \\
\text { in reality. Like the small actors are } \\
\text { demanding, higher value added products } \\
\text { [are needed]. }\end{array}$ \\
\hline 11 & $\begin{array}{l}\text { In my opinion examples such as wood- } \\
\text { based textile fibers, bio-composites, } \\
\text { plastics are product groups, by which we } \\
\text { can increase with value added. }\end{array}$ \\
\hline 12 & $\begin{array}{l}\text { I would like to have more of a "we" attitude } \\
\text { in Finland. We could be the Silicon Valley of } \\
\text { the forest industry. We have always been in } \\
\text { the top three with the Swedish and the } \\
\text { Canadians, but now we have an } \\
\text { opportunity to prove it. }\end{array}$ \\
\hline 13 & $\begin{array}{l}\text { If the state or an independent organization } \\
\text { would make it its business to promote a } \\
\text { "we" attitude and our Finnish products, } \\
\text { that might bring people together. }\end{array}$ \\
\hline 14 & $\begin{array}{l}\text { Collaboration between large-scale actors } \\
\text { over resources and smaller scale companies } \\
\text { in the manner that they trust each other. I } \\
\text { believe that small companies are often } \\
\text { afraid that large companies will steal their } \\
\text { good ideas. I don't know what could be } \\
\text { done to eliminate that fear. }\end{array}$ \\
\hline 15 & $\begin{array}{l}\text { The growth of the forests have accelerated. } \\
\text { So there will probably be enough raw } \\
\text { materials for slightly larger sustainable } \\
\text { utilization than currently, not very much } \\
\text { though. And hopefully it [forest resources] } \\
\text { can continue to be utilized and managed } \\
\text { well. }\end{array}$ \\
\hline 16 & $\begin{array}{l}\text { From the Finnish perspective, two actions } \\
\text { rise in importance above others. Firstly, }\end{array}$ \\
\hline
\end{tabular}




\begin{tabular}{|c|c|}
\hline & $\begin{array}{l}\text { make sure that the Finnish forest continues } \\
\text { to grow, being thus a solution mitigating } \\
\text { climate change. Secondly, increase the } \\
\text { value added and focus on long-lived } \\
\text { products. }\end{array}$ \\
\hline 17 & $\begin{array}{l}\text { We are at a turning point. A strategy } \\
\text { strongly focusing on economies of scale } \\
\text { alone does not work anymore. You can be } \\
\text { number one in specific areas and build } \\
\text { huge facilities and a make profit from that. } \\
\text { But at the same time there is a need to } \\
\text { build smaller and more agile facilities to } \\
\text { utilize the valuable raw material efficiently. } \\
\text { In the coming decade we will probably be in } \\
\text { the middle of this type of transition. }\end{array}$ \\
\hline 18 & $\begin{array}{l}\text { On top of that, it has become quite } \\
\text { challenging to predict the development of } \\
\text { the global economy. This in turn increases } \\
\text { the uncertainty in our business } \\
\text { environment. }\end{array}$ \\
\hline 19 & $\begin{array}{l}\text { Our bioeconomy strategy, as great as it is, is } \\
\text { still in its infancy. It's still unconnected to } \\
\text { the everyday realities of companies, both } \\
\text { big and small. }\end{array}$ \\
\hline 20 & $\begin{array}{l}\text { I don't see in that way, I don't know what's } \\
\text { longed for in it [the FBS vision]. Of course } \\
\text { every company makes its own decisions. }\end{array}$ \\
\hline 21 & $\begin{array}{l}\text { The FBS vision is not as clear as it used to } \\
\text { be } 15 \text { years ago, before the demand for } \\
\text { paper started to decrease. It was, in a way, } \\
\text { a simpler world whereas now, in this new } \\
\text { situation, I can easily understand that this } \\
\text { creates insecurities. [...] But I hope that this } \\
\text { is only temporary, and when we get the } \\
\text { financial situation improved, we can try to } \\
\text { develop value added for the next } 13 \text { years } \\
\text { again. }\end{array}$ \\
\hline 22 & $\begin{array}{l}\text { From our perspective, there is a lot of } \\
\text { messing around on the smaller scale. I } \\
\text { believe it's true that a vision you can link } \\
\text { the small companies to is missing. }\end{array}$ \\
\hline
\end{tabular}

